\title{
The impact of landscape aesthetic and ecological qualities on public preference of planting types in urban green spaces
}

\author{
Maija Veinberga, Daiga Skujāne, Pēteris Rivža, Latvia University of Life Sciences and Technologies
}

\begin{abstract}
Landscape preference in relation to human perception of landscape ecological and aesthetic qualities analysed in different studies. The importance of both qualities is highlighted especially for urban green spaces, where the enhancement of environment quality in conjunction with providing high level aesthetics is becoming a topical issue. This paper analyses seven planting types in urban green spaces in accordance with six landscape ecological and aesthetic qualities. Therefore the aim of this research is to investigate which planting type inhabitants and tourists from four Latvian cities prefer more. Planting types were evaluated according to landscape ecological and aesthetic qualities - attractiveness, naturalness, neatness, necessity of care, wilderness and safety. The method of image simulations of the different planting type alternatives was used. The research results showed a correlation between the landscape preference and respondent's gender, level of education and place of residence. The research did not display differences in landscape preference in terms of specific regional characteristics of the four selected cities. Results of this research could be used in the decision-making process for development of new and revitalization of current green spaces in the researched cities.
\end{abstract}

Keywords: landscape preference, urban planning, aesthetics, ecology, public survey, landscape scenarios, landscape architecture

\section{Introduction}

An assessment of landscape aesthetic and ecological qualities is related to human preference or attitude to different landscapes [33]. Landscape preference is an interconnected process formed by perception, cognition and evaluation of certain landscape and its qualities [17; 23]. It is a complex matter consisting of the physical characteristics of the place, sight (qualities, dimension and scale of observed landscape, openness or enclosed nature of the view, view point etc.) and the observer's mental and psychological aspects (personal experience, education, place of residence etc) $[17 ; 13 ; 30 ; 5]$. In most studies, human perception of certain landscape is evaluated using static representation of the environment-photos etc. [34].

There are various theories on the specifics of human perception in terms of landscape preference (preference of young and old people, landscape professionals and non-professionals, residents of different places etc.). Preference creates an immediate and direct complex interaction between the landscape observer and the environment. Primarily there are specific landscape elements which influence landscape preference [17], for example, natural looking landscape with tree groups or water elements, which gives the possibility for views across the landscape $[23 ; 7 ; 3 ; 34]$.

Landscape preference and interpretation of its aesthetics and ecological qualities is formed by visual, sensorial (hearing, touch, smell, taste) and cognitive perception - the observer's previous experience and interpretation of previously gained

information [25; 27; 39; 34]. Landscape preference is also influenced by genetic / biological and cultural factors $[6 ; 3 ; 34]$. Biological theories highlight a correlation between the observer and his/her place of origin, for example there are advantages of views from places which allow observations of the surroundings and at the same time provide a refuge $[1 ; 2 ; 6 ; 10 ; 31 ; 34]$. Other studies have emphasized the differences in perception of young people and adults based on structural changes of the African landscape in recent years. The results of the research showed that young people like the savannah more than local forest landscapes, but adults often remarked on the attractiveness of more familiar forest landscape $[23 ; 7 ; 34]$. Landscape aesthetician S. Bourassa [6] interpreted various different empirical studies, which demonstrate a high preference for landscapes aesthetic qualities that are formed from tree canopies and open ground level, as evidence for biological limitations and benefits of natural landscapes $[6 ; 23 ; 34]$. Also the research of the forest landscape confirms that the preference of panorama views and other open sights is related to prospect-refuge theory, where it is believed that there are two necessities: first, to open the views that provide information about the environment, and, secondly, to have a place to hide $[1 ; 16]$, thus fallen trees or covered sights can be correlated to risk of attack or barrier for running away [31].

Information processing theories indicate that different knowledge influences the preference of landscape aesthetic and ecological qualities. Legibility theory by Kevin Lynch points at human 
preference of urban landscapes with clear wayfinding - landscapes with clear landmarks, corridors and nodes [20; 23; 34]. Rachel and Stephen Kaplans developed an information processing theory that explains landscape preference with four key elements. This theory generalizes the most attractive landscapes using landscapes of complexity and mystery for human exploring and landscapes of coherence and legibility for understanding $[18 ; 23 ; 14 ; 34]$. Another theory by Kaplans - Attention Restorative theory - is based on natural environment which offers four factors for human recreation: being away, fascination, extent and compatibility. These are not usually offered by the daily urban environment $[18 ; 28 ; 34 ; 37]$. Cultural traditions also have a direct impact on the landscape. People believe that the yard, park, forest or city should look in a certain way [22; 23]. The concept of natural landscape has historically evolved from human experience, traditions and social norms [22]. There are generally accepted norms and traditions, for the site-specific landscape, for example, in rural areas - a natural green space, in a big city - human influenced, densely populated, architecturally scenic area $[22 ; 11 ; 29]$. Urban green spaces can be used for biodiversity conservation, natural habitat restoration, sustainable management, ecosystem services and the overall improvement of city health, so it is important to see how these areas will be accepted by city residents and tourists $[23 ; 29 ; 19]$.

In Latvia there have been a number of regional development studies undertaken within the different disciplines which consider attractiveness of cities for residents and visitors $[32 ; 9 ; 38]$. In the framework of those studies significant aspects for increasing the attractiveness of the city have been highlighted. Those were well maintained historic heritage buildings and sites, modern architecture, accessible for public nature areas and urban green spaces [32; 9]. Studies also showed that urban green spaces are very important for the shaping the image and identity of the city, as well as for improving the ecological quality of the urban environment. Therefore urban green spaces should meet a certain level of ecological and aesthetic quality.

Notwithstanding the appearance of new design ideas, materials and technologies in urban green spaces in Latvia in recent years, the ecological and aesthetic qualities of green spaces developed in the Soviet era are still strongly influenced by the former political system and ideology [26] In some cases, the infrastructure of parks and gardens have been destroyed and degraded, some of the areas are even abandoned which has promoted the spontaneous appearance and development of wildlife and high biodiversity. Those areas now are under the question - to be developed as ornamental squares and gardens or very naturalistic parks with greater biodiversity and important ecological quality. Therefore, a new knowledge is needed that may support the way in which decision-making on development of green spaces will be directed.

The aim of this study is to assess public preference of the ecological and aesthetic qualities of different types of plantings in urban green spaces which were created in Latvian cities during the Soviet era to detect the factors influencing the choice of the respondents. The following tasks were set to achieve the aim of study: to develop models (alternatives) of the seven types of plantings; to analyse them according to six landscape ecological and aesthetic qualities by carrying out a survey of locals and visitors; to investigate respondents` preferences of alternatives of different planting types in the urban green spaces of four Latvian cities; to detect factors influencing the respondents' choice and preference of definite planting type.

\section{Materials and Methods \\ Research area}

Four Latvian cities (Liepaja, Jelgava, Rezekne and Valmiera) were selected for research of aesthetic and ecological qualities of plantings, taking into account the following criteria: 1) each city represents different historic region of Latvia (Kurzeme, Zemgale, Latgale and Vidzeme) and Latvian planning region; 2) each city represents one of geobotanical regions; 3 ) the cities are related and comparable by area, population and green structure (Figure 1).

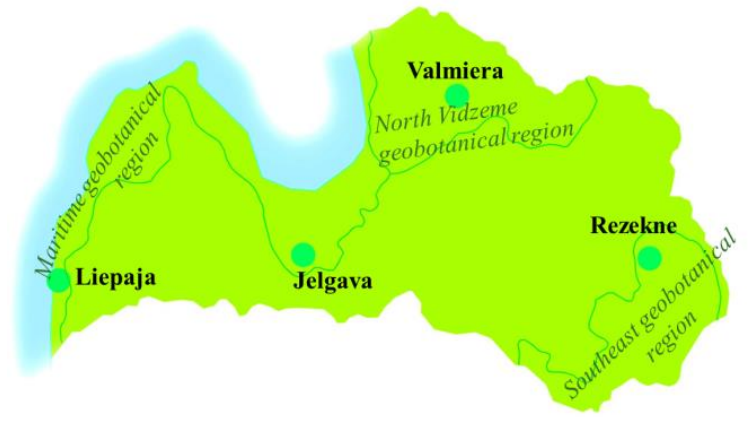

Fig. 1. Location of the selected four cities on a map of Latvia. Created by M. Veinberga.

Four popular green spaces were chosen in the four selected cities (most visited, includes a daily route for inhabitants, located in a densely populated city district). All selected green spaces were created in the Soviet era and now have a need for an improvement. Considering that, this is the stage where there is potential to choose the best future scenario for the selected green spaces - conventional artificial landscape or natural and wild park. Currently in Latvia, there are some new ideas appearing which relate to eco-friendly and naturalistic green space planning and management. However, there is still a strong influence from the 


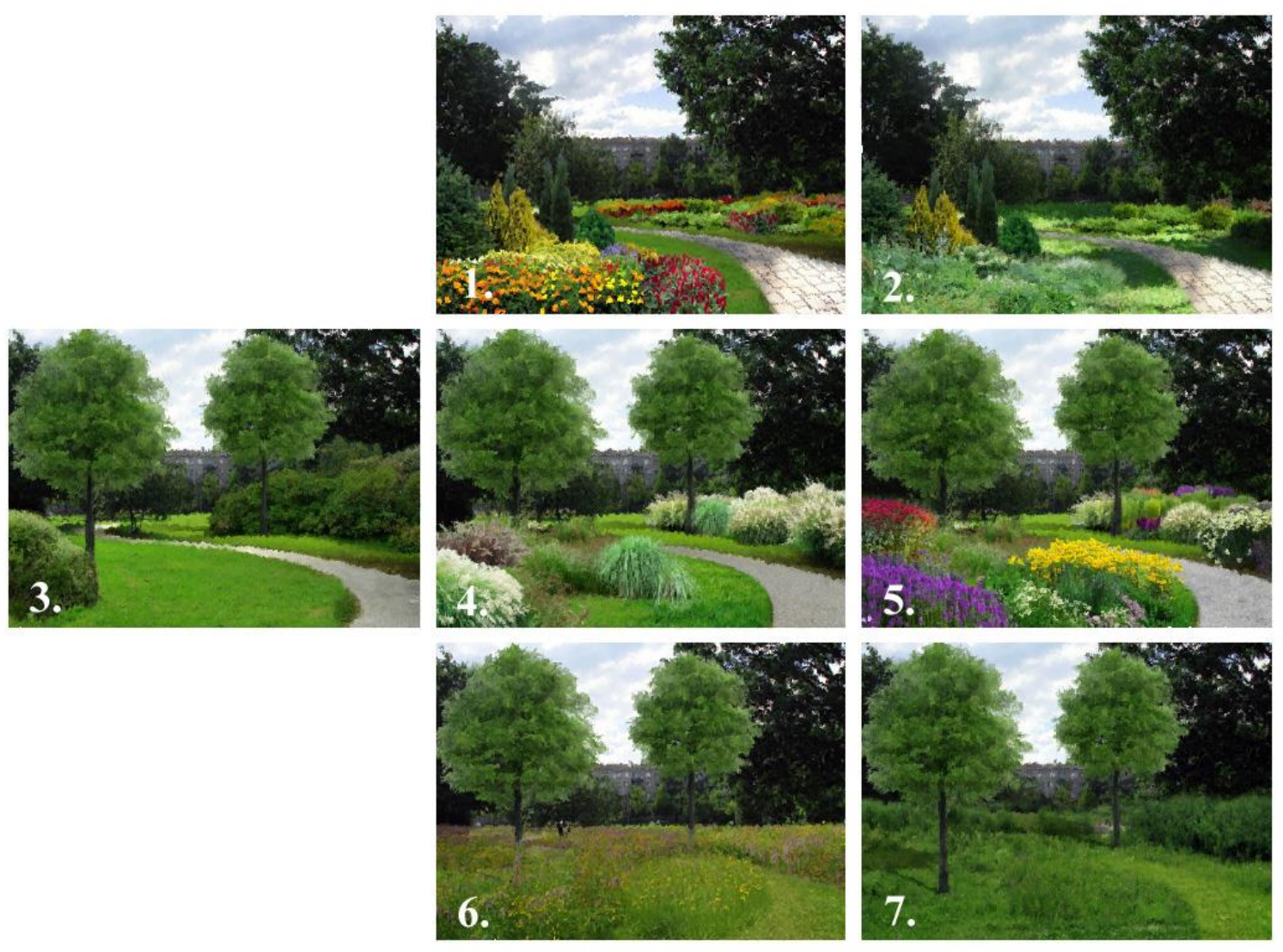

Fig. 2. Seven alternatives of different plantings in Jelgava. Created by M. Veinberga.

past planning of public green structure, which maintains traditional, verified design estranged from nature and characterized with wide areas of artificial and ornamental materials, geometric forms and planting which is not typical for the Latvian climate.

\section{Methodology}

In the framework of the current research, seven alternatives of different planting types were developed by using image simulations with photomontage. The image simulation method is most often used when consulting with the general public or experts on various landscape scenarios and alternatives. Photomontages are used in different forest landscape research $[16 ; 15]$, the evaluation of street greenery [35], and the selection of maintenance scenarios for green spaces $[19 ; 37 ; 12]$, rural landscapes [4] and suburban landscapes [21]. This method was used in a suburban landscape study in USA. Inhabitants of the Minneapolis metropolitan area evaluated seven landscape images in terms of five characteristics: attractiveness, care, neatness, naturalness and maintenance [21]. In this landscape assessment, the complete results can be obtained when assessing landscape preference depending on the respondent's gender, ethnicity, education and profession [16], using specific aspects related with variations of different landscape elements [4].
Within the current research, photomontages in Adobe PhotoShop software were applied to four photos of the most popular urban green spaces located in the central areas of the researched cities. Colour photographs that were used in the image simulation were taken on sunny days in Latvia in summer 2012.

Seven planting alternatives were developed by combining image simulations with photomontage. In all alternatives there were varied improvements to the site through varying the proportion and variety of plants. Plants suitable for the Latvian climate were used in image simulations. Alternatives were developed which ranged from a very conventional landscape with ornamental planting to a more wild and naturalistic landscape. The alternatives provide the presence of aesthetic and ecological qualities in different levels (Figure 2). There were lawn and ornamental plantings - evergreen plants and annuals in the Alternative 1, and overgrown park plantings, where a part of grass is replaced with wild (native) vegetation in the Alternative 7. One of the alternatives showed a conventional landscape as it would look without care and cultivation - unmown lawn and weeds instead of annuals in flowerbeds (Alternative 2). The remaining alternatives for plantings presented different levels of maintenance with focus on increasing an ecological quality of plantings. 
Comparison of respondents' data and statistical data of Latvia.

Source: questionnaires of respondents and data of Central Statistical Bureau of Latvia

\begin{tabular}{|c|c|c|c|c|c|c|c|c|c|c|}
\hline \multirow[b]{2}{*}{ Place of residence } & \multicolumn{8}{|c|}{ Data of respondents, 2015} & \multirow{2}{*}{\multicolumn{2}{|c|}{$\begin{array}{c}\text { Total in Latvia, } 2013 \\
\%\end{array}$}} \\
\hline & \multicolumn{2}{|c|}{ Liepaja } & \multicolumn{2}{|c|}{ Jelgava } & \multicolumn{2}{|c|}{ Rezekne } & \multicolumn{2}{|c|}{ Valmiera } & & \\
\hline Detached house & \multicolumn{2}{|c|}{20} & \multicolumn{2}{|c|}{25} & \multicolumn{2}{|c|}{16} & \multicolumn{2}{|c|}{14} & \multicolumn{2}{|c|}{26.0} \\
\hline $\begin{array}{r}\text { Part of detached house } \\
\text { or terraced house }\end{array}$ & \multicolumn{2}{|c|}{1} & \multicolumn{2}{|c|}{0} & \multicolumn{2}{|c|}{1} & \multicolumn{2}{|c|}{1} & \multicolumn{2}{|c|}{3.7} \\
\hline $\begin{array}{r}\text { Apartment in apartment house with } \\
\text { less than } 9 \text { apartments }\end{array}$ & \multicolumn{2}{|c|}{13} & \multicolumn{2}{|c|}{9} & \multicolumn{2}{|c|}{5} & \multicolumn{2}{|c|}{8} & \multicolumn{2}{|c|}{8.5} \\
\hline $\begin{array}{r}\text { Apartment in apartment house with } \\
10 \text { or more apartments }\end{array}$ & \multicolumn{2}{|c|}{51} & \multicolumn{2}{|c|}{59} & \multicolumn{2}{|c|}{27} & \multicolumn{2}{|c|}{25} & \multicolumn{2}{|c|}{61.5} \\
\hline Other & \multicolumn{2}{|c|}{3} & \multicolumn{2}{|c|}{5} & \multicolumn{2}{|c|}{6} & \multicolumn{2}{|c|}{2} & \multicolumn{2}{|c|}{0.2} \\
\hline Education & $\mathrm{M}$ & $\mathrm{F}$ & $\mathrm{M}$ & $\mathrm{F}$ & $\mathrm{M}$ & $\mathrm{F}$ & $\mathrm{M}$ & $\mathrm{F}$ & Male & Female \\
\hline Lower than elementary education & 0 & 0 & 0 & 0 & 0 & 0 & 0 & 0 & 32545 & 40095 \\
\hline Elementary education & 2 & 0 & 0 & 0 & 0 & 0 & 0 & 1 & 163448 & 169085 \\
\hline High school education & 10 & 8 & 11 & 4 & 7 & 7 & 9 & 7 & 193182 & 229662 \\
\hline Professional high school education & 5 & 6 & 2 & 2 & 3 & 4 & 3 & 7 & 259359 & 276711 \\
\hline University or college degree & 15 & 40 & 23 & 51 & 7 & 26 & 4 & 19 & 142950 & 261419 \\
\hline PhD degree & 0 & 2 & 0 & 5 & 0 & 1 & 0 & 0 & 3166 & 2750 \\
\hline
\end{tabular}

The Alternative 1 was developed in traditional way by using annual flowers and evergreen plants that require regular care and financial resources for maintenance, and do not provide habitats for wild animals and diversity of native vegetation. However evergreen plants will be visually appealing in the autumn and winter and flowerbeds will not remain empty. The Alternative 2 expanded on this style but left the plants unmaintained. A variety of weeds appear next to the ornamental bushes; the area loses its visual attractiveness, but starts to attract a variety of wild animals. The Alternative 3 features mown lawn, trees and bushes. This alternative is financially advantageous because there is no need for seasonal change of plants and regular maintenance. It provides a habitat for small wild animals, but is not so colorful and attractive for people. In the Alternative 4 a part of the lawn was replaced by grassy perennials which are not so often used in Latvia. However, grassy perennials are a costeffective solution, they will be magnificent all year round, and such planting is widely used in North American parks and gardens. In the Alternative 5 a large part of lawn was replaced by different grassy and colourful perennials that are already used in Latvian plantings. Alternative 4 and Alternative 5 provide the habitat and food for a variety of birds and small mammals. The Alternative 6 developed as wildflower meadow with characteristic wild plant species. The Alternative 7 represented the largest biodiversity; it was made of a combination of native bushes and trees, and plants of meadows. The Alternative 7 was made with wild vegetation including the photos of typical local natural landscape (Perkone Channel coast in Liepāja, Pasta Island in Jelgava, natural vegetation of Rēzekne
River in Rēzekne and Gauja Valley in Valmiera). Both of the last alternatives show the largest biodiversity and the most natural area for wildlife habitat. These options can also attract unwanted animals for urban population, thereby endangering the safety of visitors of the territory (ticks, wasps). There is no need for regular mowing of the lawn like there is in other alternatives; however, the flowering period of the plants is limited.

Four different questionnaires were electronically prepared for each of the research cities by using the photomontages on photos of planting areas from selected green spaces of each city - Liepaja, Jelgava, Rezzekne and Valmiera. Residents and visitors of the four cities were chosen as respondents because they are more familiar with the current situation of the cities' green spaces and have certain opinions on the further development of those areas. Respondents were asked to evaluate seven alternatives for each planting area by using six landscape aesthetic and ecological qualities - attractiveness, naturalness, neatness, necessity of care, wilderness and safety.

Attractiveness is related with scenic beauty and harmony of landscape in observer's mind. Natural vegetation, relief, water bodies and streams, and the proportion of plants in a green space identify Naturalness in the urban environment. Neatness is related to the sense of order and indicates the care about the landscape. Necessity of care is connected with Neatness and shows how much upkeep and management activities are required to increase the visual quality of landscape. Wilderness describes unmanaged, visually neglected, abandoned and wild green space and it's the extreme of Naturalness. Whereas Safety is described as humans' need for well secured and comfortable activities during time 
spent in public green spaces. These qualities were selected because they characterize aesthetic and ecological qualities of different type of public green spaces (conventional or ecological design).

291 completed questionnaires were received. Characteristics of the respondents are shown in the Table 1. The average age of respondents was 34 years; the overall age range of respondents was from 15 to 77 years. Most respondents belonged to age group from 25 to 35 years. Less than a half $(35 \%)$ of the respondents were men, more than a half $(65 \%)$ of the respondents were women.

Respondents were generally well educated; more than a half of the respondents noted that they have a university or college education, and less than one third of respondents have high school education or lower. Out of the total number of the completed questionnaires, $30 \%$ of the respondents stated that their education or occupation is related to architecture, art and design, $9 \%$ to ecology, botany, or natural sciences and $9 \%$ related to agriculture or forestry research. The majority of respondents $(82 \%)$ noted that they visit the city public green spaces on the average at least once a week. Most respondents (56\%) live in apartments in large apartment buildings with 10 or more apartments.

All four surveys were analyzed separately, so that the respondent answers for the different cities would not overlap. Respondents' answers were evaluated based on their gender, the field of education and occupation, childhood environment and place of residence. Statistic data analysis was undertaken using mathematical statistics methods with computer programmes SPSS 13.0 and MS Excel 2010.

\section{Results and Discussion}

\section{Landscape aesthetic and ecological qualities}

Respondents could evaluate seven alternatives of one green space in six landscape aesthetic and ecological qualities - attractiveness, naturalness, neatness, necessity of care, wilderness and safety. The results in the context of four cities varied (Figure 3). The most attractive alternative for respondents from Liepaja and Valmiera was Alternative 5 - planting of various perennials. The most attractive alternative for respondents from Jelgava was Alternative 1 with the conventional planting of evergreen plants and annuals. The most attractive alternatives for respondents from Rezekne were both Alternative 1 and 3 .

The assessment of landscape aesthetic quality neatness in Liepaja city showed similar results between the Alternatives 1,3 and 4. However Alternative 1 with conventional planting gained more points. In Jelgava city, neatness was found more visible in Alternative 3 comprising trees and bushes, but in Rēzekne and Valmiera neatness was found in Alternative 1 with conventional planting. The Alternative 1 was recognized as a model that requires more regular care to keep it in position shown in the photomontages in all four cities. Alternative 1 was recognized as more demanding for care also in Rēzekne. According to the answers of respondents from Liepāja and Jelgava, Alternative 3 with trees and bushes provides more safety. It is contrary to results obtained in other studies $[2 ; 24 ; 34 ; 37 ; 12]$ which express that a large amount of bushes can lead to a perception of a dangerous and unsafe situation in parks, especially during the night-time. By the contrast, in Valmiera and Rēzekne Alternative 1 was considered as safe.

In Jelgava and Valmiera, the ecological quality naturalness was marked in the Alternative 6 which comprised wild flower meadow. Alternative 7 in Liepaja city with the wild landscape also gained high value of naturalness. Alternative 3 was considered the most natural landscape in Rēzekne and Liepāja. In Liepāja and Valmiera the ecological quality wilderness was marked by respondents in Alternative 7 representing the natural landscape as the wild one, but in Jelgava and Rēzekne, the majority of respondents noted that Alternative 6 with flowering meadows was a wild landscape. This can be explained by the different wild flowers used in photomontages that looked comparable to decorative not wild greenery to the respondents (such as poppy in the sixth alternative of green space in Liepaja).

Using statistical software, relative normalized means where the average is equal to zero (Z-Score) of the six landscapes aesthetic and ecological qualities were calculated. This evaluation took into consideration all the answers given by 291 respondents, regardless of their affiliation to different cities. The six qualities were evaluated in the context of the seven alternatives of planting types (Figure 4). The Attractiveness and Neatness qualities gained similar positions in five of the seven alternatives. Differences were shown in assessment of Alternative 3 and 5, because the fifth alternative with planting of colourful perennials is recognized as more attractive, but the third alternative with trees and bushes as neater. In the natural alternatives (6 and 7) Safety, Attractiveness, Neatness and Necessity of care modelled one group, but Naturalness and Wilderness another group.

Alternative 1 with a traditional planting style was perceived as attractive, neat, and safe, however, it has a high necessity of care. Similar situations were observed in Alternative 4 and 5 with different planting types of perennials and trees. These alternatives were perceived as very attractive, neat with necessity of care, but Alternative 4 does not need such regular care as Alternative 5 and overall it was recognized safer. Vegetation of different herbaceous plants in Alternative 1, 4 and 5 


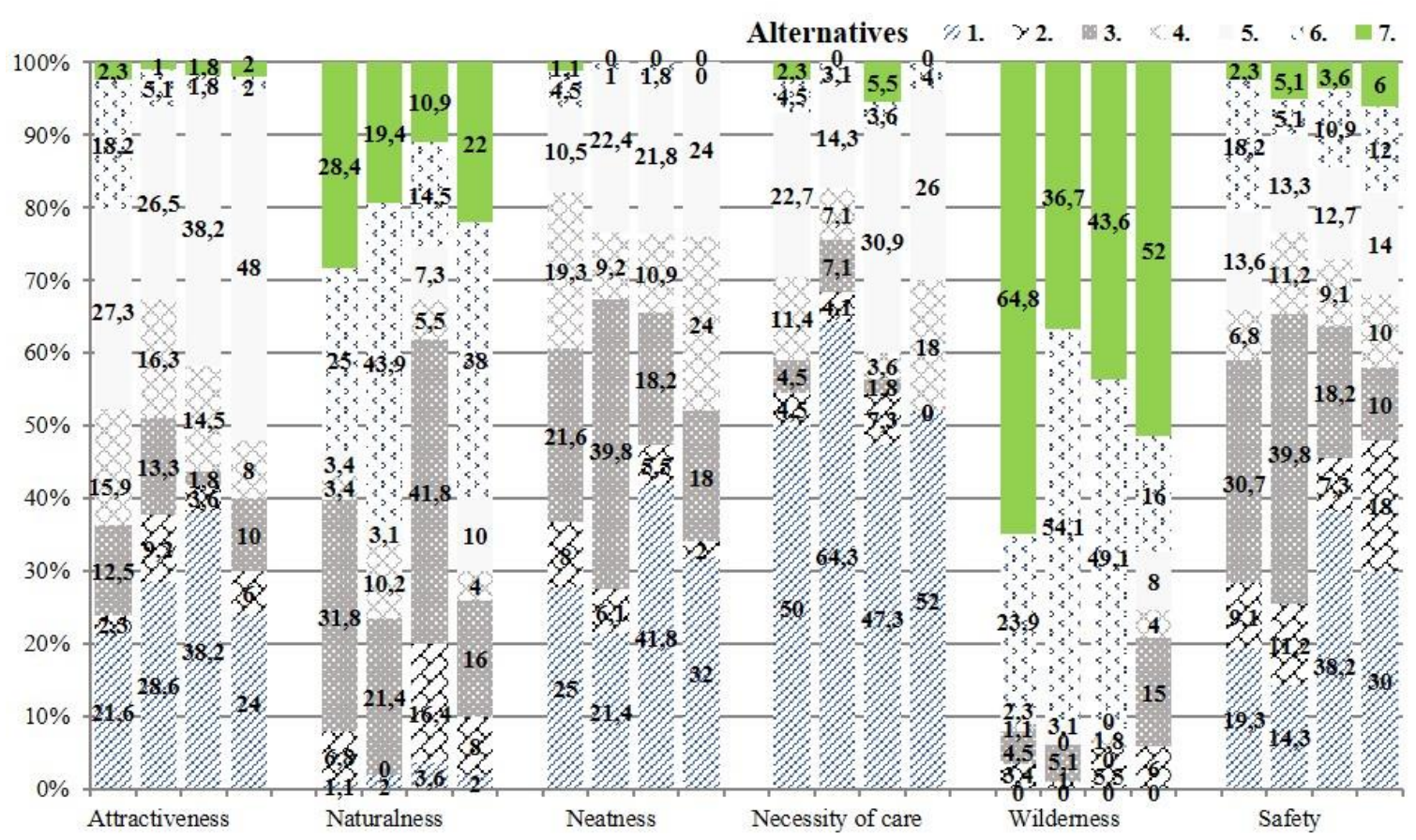

Fig. 3. Evaluation of seven alternatives of urban green spaces, \%. The order of cities for each landscape quality follows: Liepaja, Jelgava, Rezekne, Valmiera. Created by M. Veinberga.

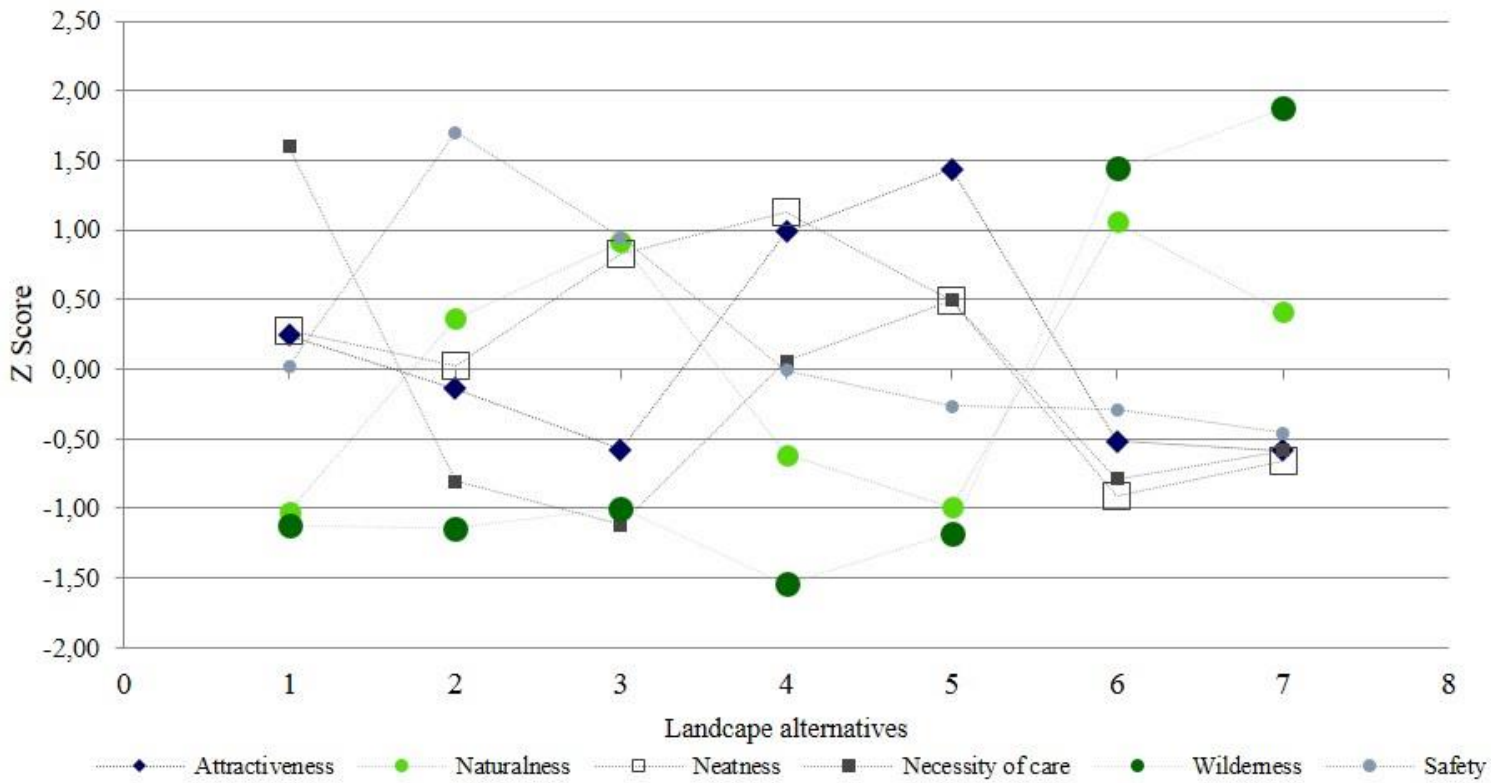

Fig. 4. Relative normalized means for landscape characteristics. Created by M. Veinberga.

were recognized as less natural than the trees and bushes in Alternative 3 and the wildflower meadow in the Alternative 6. Unmanaged planting in Alternative 2 was considered as natural, also safe, but unattractive and not neat, despite the fact that this alternative was chosen by very small number of respondents. The third alternative with planting of trees and shrubs was evaluated as neat, natural, safe, but not so attractive and demanding care more than other alternatives. The first five alternatives that are the most common in Latvian urban green spaces, did not receive a high value of wilderness.

\section{Landscape preference}

In the comparison of alternatives mostly preferred by respondents, the overall results in all cities are very similar (Table 2). Alternative 5 with planting of trees and colourful perennials was considered to be the most attractive and pleasant alternative in three cities, however, in Liepaja the 
Landscape preference by responses of respondents $(\%)$

\begin{tabular}{lcccc}
\hline Alternative No, type & Liepaja & Jelgava & Rezekne & Valmiera \\
\hline 1. Conventional planting & 22.7 & 18.4 & 30.9 & 20 \\
2. Conventional planting without care & 0 & 2 & 0 & 0 \\
3. Trees and shrubs & 25 & 20.4 & 14.5 & 2 \\
4. Trees and grasses & 14.8 & 19.4 & 12.7 & 10 \\
5. Trees and different perennials & 22.7 & 34.7 & 34.5 & 64 \\
6. Trees and wildflower meadow & 14.8 & 4.1 & 1.8 & 2 \\
7. Wild plantings typical to the region & 0 & 1 & 5.5 & 2 \\
\hline
\end{tabular}
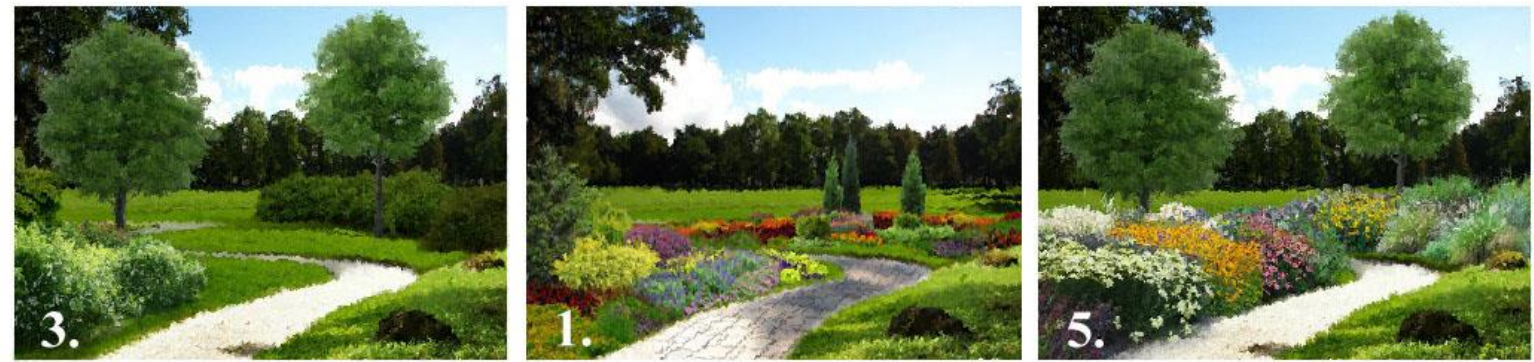

Fig. 5. The most preferred planting types of respondents of Liepaja, alternatives 3, 1, 5. Created by M. Veinberga
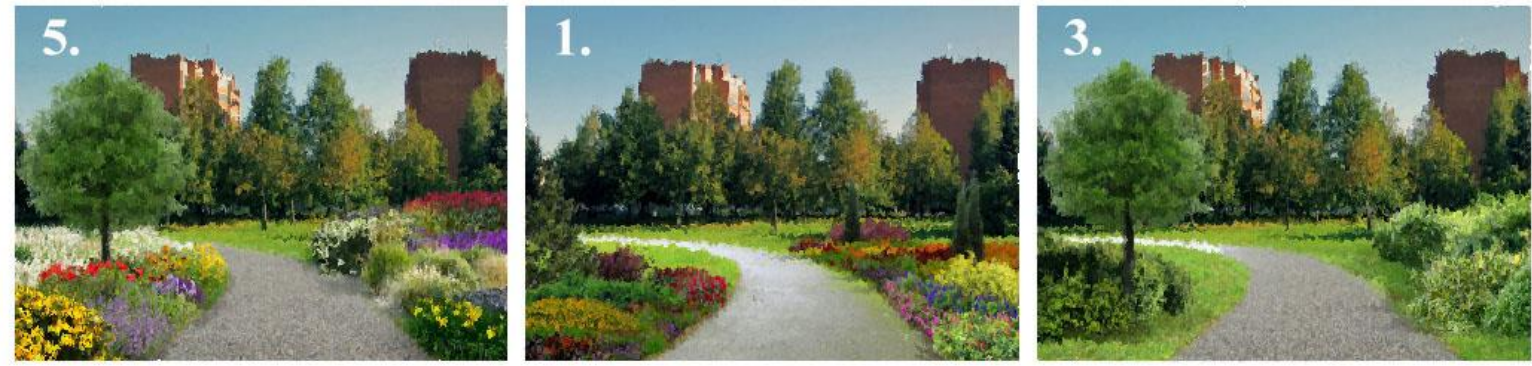

Fig. 6. The most preferred planting types of respondents of Rezekne, alternatives 5, 1, 3. Created by M. Veinberga

most attractive was recognized as the third alternative with trees and shrubs.

Respondents from Jelgava preferred Alternative 5 with planting of trees and different perennials most of all. Also, Alternative 3, 4 and 1 were often mentioned as the most attractive. The scores obtained by those alternatives were very close to each other, but lag behind the most pleasant alternative.

Among the respondents of Liepāja city, Alternative 3 with planting of trees and shrubs was recognized as the most pleasant (Figure 5). This can be explained with the following high-rated Alternative 5, 1, 6 and 4 that divided the rest of the majority of points. In the Liepaja photomontage, Alternative 6 with poppies in the wild flower meadow was marked as most attractive as in the same alternative developed for other cities. It is highlighting that colourful local plant species in the planting areas of urban green spaces will be always seen more attractive for residents than the humblest plants, although they will be ecologically more valuable [23].

The results of the Rēzekne survey showed that respondents selected Alternative 1 with evergreen plants and annuals as more pleasant (Figure 6). Alternative 5 with planting of different perennials and trees also gained the greatest support among respondents. Other alternatives had a very similar distribution and lagged behind the two most commonly chosen alternatives.

Respondents of Valmiera liked Alternative 5 with planting comprising different perennials most of all. It received more than half of the respondents' points (Figure 7). Alternative 1 with conventional planting and Alternative 4 with planting of grassy perennials and trees were also recognized as pleasant. Respondents of Valmiera compared to all of the other respondents did not select the planting of Alternative 3 with trees and shrubs as often. The reason for that could be the existing situation of the researched park - the large trees and shrubs in the park make the overall image appear dark and gloomy.

The following analysis of the responses of the respondents according to their field of education, gender, level of education, the current housing type, place of residence and childhood environment was carried out. Correlation analysis indicated that 

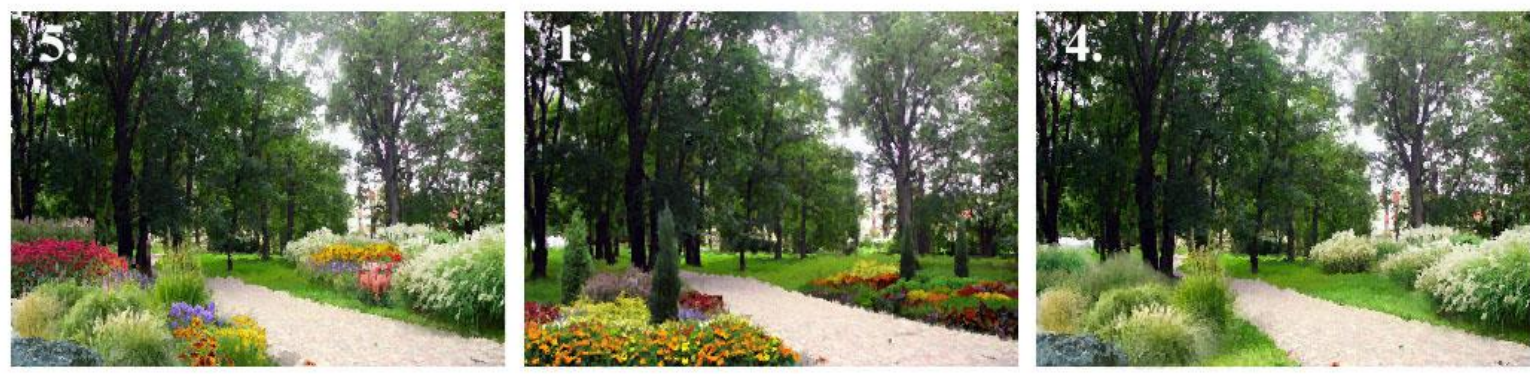

Fig. 7. The most preferred planting types of respondents of Valmiera, alternatives 5, 1, 4. Created by M. Veinberga.

TABLE 3

Correlation of landscape preference and descriptive of respondents

\begin{tabular}{|c|c|c|c|c|c|c|c|c|c|}
\hline \multirow{4}{*}{$\begin{array}{l} \\
\text { Landscape } \\
\text { preference }\end{array}$} & & \multirow{2}{*}{$\begin{array}{c}\text { Gender } \\
, 208^{* *}\end{array}$} & \multirow{2}{*}{$\begin{array}{l}\text { Education } \\
\text { level }\end{array}$} & \multicolumn{2}{|c|}{$\begin{array}{ll}\text { Field of } & \mathrm{P} \\
\text { education } & \mathrm{re}\end{array}$} & $\begin{array}{l}\text { lace of } \\
\text { esidence }\end{array}$ & $\begin{array}{l}\text { Location } \\
\text { (city or } \\
\text { country) }\end{array}$ & \multicolumn{2}{|c|}{$\begin{array}{l}\text { Childhood } \\
\text { environment }\end{array}$} \\
\hline & $\begin{array}{l}\text { Pearson } \\
\text { Correlation }\end{array}$ & & & -.015 & & 066 & .063 & & $\overline{047}$ \\
\hline & $\begin{array}{l}\text { Sig. } \\
\text { (2-tailed) }\end{array}$ & .000 & .008 & .794 & & 260 & .288 & & 423 \\
\hline & $\mathrm{N}$ & 291 & 291 & 291 & & 291 & 291 & & 291 \\
\hline \multicolumn{10}{|c|}{ Crosstab analysis of landscape preference } \\
\hline & & & 1. & 2. & 3. & 4. & 5. & 6. & 7. \\
\hline \multirow[b]{2}{*}{ Gender } & Male & & $27.7 \%$ & $.0 \%$ & $32.7 \%$ & $14.9 \%$ & $16.8 \%$ & $5.0 \%$ & $3.0 \%$ \\
\hline & Female & & $\begin{array}{l}19 . \\
5 \%\end{array}$ & $1.1 \%$ & $9.5 \%$ & $15.3 \%$ & $46.3 \%$ & $7.4 \%$ & $1.1 \%$ \\
\hline Total & & & $22.3 \%$ & $.7 \%$ & $17.5 \%$ & $15.1 \%$ & $36.1 \%$ & $6.5 \%$ & $1.7 \%$ \\
\hline \multirow{2}{*}{$\begin{array}{l}\text { Level of } \\
\text { education }\end{array}$} & \multicolumn{2}{|c|}{ With higher education } & $18.1 \%$ & $\begin{array}{l}1.0 \\
\%\end{array}$ & $17.6 \%$ & $4.6 \%$ & $37.8 \%$ & $8.8 \%$ & $2.1 \%$ \\
\hline & \multicolumn{2}{|c|}{$\begin{array}{l}\text { Without higher } \\
\text { education }\end{array}$} & $30.6 \%$ & $.0 \%$ & $17.4 \%$ & $16.3 \%$ & $32.7 \%$ & $2.0 \%$ & $1.0 \%$ \\
\hline Total & & & $22.3 \%$ & $.7 \%$ & $17.5 \%$ & $15.1 \%$ & $36.1 \%$ & $6.5 \%$ & $1.7 \%$ \\
\hline \multirow{5}{*}{$\begin{array}{l}\text { Place of } \\
\text { residence }\end{array}$} & Detach & house & $26.7 \%$ & $1.3 \%$ & $10.7 \%$ & $17.3 \%$ & $40.0 \%$ & $4.0 \%$ & $.0 \%$ \\
\hline & $\begin{array}{l}\text { Part of } \\
\text { or terra }\end{array}$ & $\begin{array}{l}\text { ached house } \\
\text { house }\end{array}$ & $33.3 \%$ & $.0 \%$ & $.0 \%$ & $33.3 \%$ & $.0 \%$ & $33.3 \%$ & $.0 \%$ \\
\hline & $\begin{array}{l}\text { Apartm } \\
\text { apartm } \\
\text { less tha }\end{array}$ & $\begin{array}{l}\text { in in } \\
\text { house with } \\
9 \text { apartments }\end{array}$ & $20.0 \%$ & $.0 \%$ & $22.9 \%$ & $25.7 \%$ & $28.6 \%$ & $2.9 \%$ & $.0 \%$ \\
\hline & $\begin{array}{l}\text { Apartm } \\
\text { apartm } \\
\text { 10or m }\end{array}$ & $\begin{array}{l}\text { in } \\
\text { house with } \\
\text { apartments }\end{array}$ & $21.0 \%$ & $.6 \%$ & $19.8 \%$ & $11.7 \%$ & $37.7 \%$ & $7.4 \%$ & $1.9 \%$ \\
\hline & Other & & $18.8 \%$ & $.0 \%$ & $18.8 \%$ & $12.5 \%$ & $25.0 \%$ & $12.5 \%$ & $12.5 \%$ \\
\hline Total & & & $22.3 \%$ & $.7 \%$ & $17.5 \%$ & $15.1 \%$ & $36.1 \%$ & $6.5 \%$ & $1.7 \%$ \\
\hline \multirow{2}{*}{ Location } & City & & $22.7 \%$ & $.8 \%$ & $18.8 \%$ & $14.8 \%$ & $35.2 \%$ & $5.9 \%$ & $22.7 \%$ \\
\hline & Countr & & $20.0 \%$ & $.0 \%$ & $8.6 \%$ & $17.1 \%$ & $42.9 \%$ & $11.4 \%$ & $.0 \%$ \\
\hline \multirow[t]{2}{*}{ Total } & & & $22.3 \%$ & $.7 \%$ & $17.5 \%$ & $15.1 \%$ & $36.1 \%$ & $6.5 \%$ & $1.7 \%$ \\
\hline & Centre & he city & $30.8 \%$ & $.0 \%$ & $23.1 \%$ & $3.8 \%$ & $30.8 \%$ & $3.8 \%$ & $7.7 \%$ \\
\hline \multirow{3}{*}{$\begin{array}{l}\text { Childhood } \\
\text { environment }\end{array}$} & Urban & vironment & $22.7 \%$ & $1.5 \%$ & $17.4 \%$ & $15.9 \%$ & $31.1 \%$ & $10.6 \%$ & $.8 \%$ \\
\hline & Small t & & $18.2 \%$ & $.0 \%$ & $27.3 \%$ & $18.2 \%$ & $36.4 \%$ & $.0 \%$ & $.0 \%$ \\
\hline & Rural e & ironment & $20.5 \%$ & $.0 \%$ & $15.6 \%$ & $16.4 \%$ & $42.6 \%$ & $3.3 \%$ & $1.6 \%$ \\
\hline Total & & & $22.3 \%$ & $.7 \%$ & $17.5 \%$ & $15.1 \%$ & $36.1 \%$ & $6.5 \%$ & $1.7 \%$ \\
\hline
\end{tabular}


respondent's answers to the question "Which of these planting alternatives you like the best?" mostly was influenced by gender and level of education of respondent (Table 3). The data correlation was not detected between the landscape preference and the field of education and childhood environment.

If the comparison of responses of respondents in the context of their gender would be discussed, it can be observed that women most often selected colourful planting (Alternative 5-46\%, Alternative $1-20 \%$, and Alternative 6-7\%), while men prefer simpler planting (Alternative $3-33 \%$, Alternative $1-28 \%$ and Alternative 4-15\%) (Table 4). Also the previous studies $[8 ; 7]$ regarding to the differences of colour choice between both genders, found that men choose specific colours (mostly primary colours), but the women's choice is less homogeneous; they tend to choose more secondary colours and a variety of tonal gradations.

The answers of respondents in the context of childhood environment showed that people who once lived in rural areas, most often chose Alternative 5 (43\%), as well as the people who lived in small towns or in the suburban areas of cities (31 and $36 \%$ respectively). In addition, they tend to choose the Alternative 1 (23 and $18 \%$ respectively) and Alternative 3 (17 and $27 \%$ respectively). People who lived in the centre of the city selected Alternative 1 (31\%), Alternative $5(31 \%)$ or a completely different Alternative 7 ( $8 \%$ ), which can be explained by a lack of natural landscapes nearby. The level of education also influenced the choice of respondents because respondents with higher education preferred more unconventional greenery that is not currently so popular and visible in urban green space, but respondents with a lower level of education chose alternatives that they can see in everyday landscapes in their nearby neighbourhoods. A large dispersal was detected between respondents of different education levels within the results of the five most popular alternatives of planting style. Respondents with a lower level of education more often preferred the Alternative 1, which is most often seen in green spaces in the city center $-31 \%$ of respondents without higher education as opposed to $18 \%$ of respondents with higher education. Respondents with higher education more often noted the Alternative 1 as more care demanding than respondents with a lower education level (61\% vs. $43 \%)$. It was also noted for Alternatives 5 and 6. Alternatives 1,5 and 6 require more care, that means that the differences of assessment were dependent of respondents' knowledge [24]. In this study there were no particularly different answers detected from respondents with ecological knowledge, as it was observed in other similar studies, where respondents with an education in ecology selected more natural landscapes $[23 ; 29 ; 19]$.

The residents of private houses frequently chose Alternatives 5 and 1 (accordingly $40 \%$ and $27 \%$ ), while residents of apartment buildings chose Alternatives 1, 3 and 5 (21\%, 20\% and $37 \%$ respectively), but residents of small houses selected Alternatives 3, 4 and 5 (23\%, $26 \%$ and $27 \%$ ). It highlights that residents of private houses perceive green spaces as a continuation of their surroundings and, therefore, prefer the type of planting which contain plants already seen in their own gardens. Residents of private houses less often chose Alternatives 3, 6 and 7 (11\%, $4 \%$ and $0 \%)$. The reason could be the experience of respondents of care for the environment and their desire for more complex and colourful, less simple planting. Similar results were shown in the studies of forest landscapes [36], where the residents of private houses were more particular to maintenance of the forest, whereas apartment house dwellers had no objection to the left behind trees and dense undergrowth of suburban forests. In other Latvian research on urban forest alternatives, people preferred intensively managed alternatives [15]. The results of this study differ from the results of the research in USA [24], where the owners of private houses chose more traditional landscape design with mown lawns and ornamental plants. Overall, the results of the study showed that, according to the previous studies $[21 ; 16 ; 7$; $24 ; 15]$, the choice of people was dominated by the park landscape that depicts the "savannah type" plantings with low vegetation, good accessibility and transparency.

\section{Conclusions}

Attractive landscape is related to a neat, orderly and safe landscape, as opposed to natural landscape, which is related to wild elements and human non-intervention in natural processes. However, man-made, neat and orderly landscapes are related to naturalness in people's perception because urban planting with trees, shrubs and perennials was assessed as more natural and visually attractive than the most common traditional Latvian urban planting with annuals and evergreen plants.

The study in the context of four Latvian cities did not indicate significant differences in the respondents' choice of four different urban environments. It is possible that urban green spaces in human perception do not refer to regional characteristics and specifics of the wild environment that would otherwise be seen in the studies of open countryside or forest landscape.

Landscape preference in the perception of city residents and visitors is mostly influenced by human gender, level of education, place of residence and childhood environment. Planting which utilises different flowering and grassy perennials, bushes and trees are perceived as the most attractive and pleasant alternatives by residents and visitors from researched cities. Women most often choose bright floral planting types, while men prefer simple planting types comprising trees and shrubs that do not require special care. 


\section{References}

1. Appleton, J. Prospects and refuges revisited. Landscape Journal, 1984, Vol. 3, p. 91-103.

2. Appleton, J. The experience of landscape (Revised ed.). New York: John Wiley and Sons, 1996. 296 p.

3. Baker, J.M. Dialectic Aesthetics: The Landscape aesthetics of Steven Bourassa and the Architecture aesthetics of Roger Scruton. Ms Thesis. The University of Texas, Arlington, USA, 2009, 158 p.

4. Barroso, F.L., Pinto-Correia, T., Ramos, I.L., Surová, D., Menezes, H. Dealing with landscape fuzziness in user preference studies: Photo-based questionnaires in the Mediterranean context. Landscape and Urban Planning, 2012, Vol. 104(3), p. 329-342.

5. Bell, S. Landscape: Pattern, Perception and Process (2nd ed.). New York: Routledge, 2012. 348 p.

6. Bourassa, S.C. The Aesthetics of Landscape. London: John Wiley and Sons, 1991. 256 p.

7. Dutton, D. Aesthetics and Evolutionary Psychology. In: The Oxford Handbook for Aesthetics. Levinson, J. (ed.) New York: Oxford University Press, 2003, p. 693-705.

8. Ellis, L., Ficek, C. Color preferences according to gender and sexual orientation. Personality and Individual Differences, 2001, Vol. 31(8), p. 1375-1379.

9. Ezmale, S. Strategies for enhancing attractiveness of the cities in Latgale region. European Integration Studies, 2012, Vol. 6, p. 121-127. http://dx.doi.org/10.5755/j01.eis.0.6.1601

10. Gobster, P.H. An ecological aesthetic for Forest Landscape Management. Landscape Journal, 1999, Vol. 18, p. 54-64

11. Gobster, P.H., Nassauer, J.I., Daniel, T.C., Fry, G. The shared landscape: What does aesthetics have to do with ecology? Landscape Ecology, 2007, Vol. 22, p. 959-972.

12. Hadavi, S., Kaplan, R., Hunter, M.C. Environmental affordances: A practical approach for design of nearby outdoor settings in urban residential areas. Landscape and Urban Planning, 2015, Vol. 134, p. 19-32.

13. Hitchmough, J., Dunnett, N. Introduction to naturalistic planting in urban landscapes. The Dynamic Landscape. New York: Spon Press, 2004, p. 1-32.

14. Hofmann, M., Westermann, J.R., Kowarik, I., van der Meer, E. Perceptions of parks and urban derelict land by landscape planners and residents. Urban Forestry \& Urban Greening, 2012, Vol. 11(3), p. 303-312.

15. Jankovska, I. Rīgas pilsētas mežu apsaimniekošanas problemātika un risinājumi [Problems and Solutions in Management of Riga Urban Forests]. PhD Thesis, Latvia University of Agriculture, Jelgava, Latvia, 2013. 112 p.

16. Jorgensen, A., Hitchmough, J., Calvert, T. Woodland spaces and edges: their impact on perception of safety and preference. Landscape and Urban Planning, 2002, Vol. 60, p. 135-250.

17. Kaplan, S. Aesthetics, Affect and Cognition Environmental Preference from an Evolutionary Perspective. Environment and Behaviour, 1987, Vol. 19(1), p. 3-32.

18. Kaplan, R., Kaplan, S. The Experience of Nature: A Psychological Perspective. New York: Cambridge University Press, 1989. $340 \mathrm{p}$.

19. Khew, J.Y, Yokohari, M., Tanaka, T. Public Perceptions of Nature and Landscape Preference in Singapore. Human Ecology, 2014, Vol. 42(6), p. 979-988.

20. Lynch, K. Image of the city. Cambridge: MIT Press, 1960. 208 p.

21. Nassauer, J.I. Ecological Function and the perception of suburban residential landscapes. Managing Urban and High-Use Recreation Settings. P.H. Gobster (ed.). Minnesota: USDA Forest Service North Central Forest Experiment Station St. Paul, 1993, p. 55-60.

22. Nassauer, J.I. Culture and changing landscape structure. Landscape Ecology, 1995, Vol. 10(4), p. 229-237.

23. Nassauer, J.I. Messy ecosystems, orderly frames. In: Theory in Landscape Architecture: A Reader. Swaffield, S. R. (ed.). Philadelphia: University of Pennsylvania Press, 2002, p. 196-206.

24. Nassauer, J.I., Wang, Z., Dayrell, E. What will the neighbors think? Cultural norms and ecological design. Landscape and Urban Planning, 2009, Vol. 92, p. 282-292.

25. Ode, A. Visual Aspects in Urban Woodland Management and Planning. Doctoral Thesis, Swedish University of Agricultural Sciences, Alnarp, Sweden, 2003. 41 p.

26. Ozola, S. Synthesis of Nature and Art in Latvian Cities. Proceedings of 16th Generative Art Conference „GA2013”, 2013, p. 233-246.

27. Perry, S., Reeves, R., Sim, J. Landscape Design and the Language of Nature. Landscape Review, 2008, Vol. 12(2), p. 3-18.

28. Peschardt, K.K., Stigsdotter, U.K. Associations between park characteristics and perceived restorativeness of small public urban green spaces. Landscape and Urban Planning, 2013, Vol. 112, p. 26-39.

29. Qiu, L., Lindberg, S., Nielsen, A.B. Is biodiversity attractive? On-site perception of recreational and biodiversity values in urban green space. Landscape and Urban Planning, 2013, Vol. 119, p. 136-146.

30. Sevenant M., Antrop M. The use of latent classes to identify individual differences in the importance of landscape dimensions for aesthetic preference. Land Use Policy, 2010, Vol. 27, p. 827-842.

31. Sheppard, S. R. J. Beyond Visual Resource Management: Emerging Theories of an Ecological Aesthetic and Visual Stewardship. In: Forests and Landscapes: Linking Ecology, Sustainability, and Aesthetics, Sheppard, S. R. J., Harshaw, H. W. (eds.), New York: CABI publishing, 2001, p. 149-172.

32. Silineviča, I. The attractiveness of cities in the frame of regional development. Human Resources: The Main Factor of Regional Development, 2001, Vol. 3, p. 74-80.

33. Stūre, I. Kultūras un dabas mantojuma aizsardzības izpratne. Rīga: LU Akadēmiskais apgāds, 2004. 238 p.

34. Thompson, C.W. Landscape perception and environmental psychology. In: The Roultedge Companion to Landscape Studies. Howard, P., Thompson, I., Waterton, E. (eds.). New York: Routledge, 2013, p. 25-42.

35. Todorova, A., Asakawa, S., Aikoh, T. Preferences for and attitudes towards street flowers and trees in Sapporo, Japan. Landscape and Urban Planning, 2004, Vol. 69(4), p. 403-416. 
36. Tyrväinen, L., Silvennoinen, H., Kolehmainen, O. Ecological and aesthetic values in urban forest management. Urban forestry and Urban Greening, 2003, Vol. 1, p. 135-149.

37. Van den Berg, A. E., Jorgensen, A., Wilson, E.R. Evaluating restoration in urban green spaces: Does setting type make a difference? Landscape and Urban Planning, 2014, Vol. 127, p. 173-181.

38. Zaluksne, V., Rivza, B. Place's Image in Latvia and Pecularities of Its Perception in the Context of Place Marketing. Proceedings of the 18th International Scientific Conference "Economic Science for Rural Development", 2012, Vol. 28, p. 119-125.

39. Zigmunde, D. Estētiskās kvalitātes kritēriji urbanizētas ainavas izpētē. LLU Raksti, 2010, Vol. 25, p. 1-12 (In Latvian).

INFORMATION ABOUT THE AUTHORS:

Maija Veinberga, Dr. arch., landscape architect at Riga City Construction Board. Field of research: landscape aesthetics and ecology, urban planning, landscape assessment. E-mail: maija.veinberga23@gmail.com

Daiga Skujāne, Dr. arch., prof. at the Latvia University of Life Sciences and Technologies, specialized in fields of landscape ecology, human perception of landscape, landscape study. E-mail: daiga.skujane@ @llu.lv

Pēteris Rivža, Dr. habil. sc. ing., prof. at the Latvia University of Life Sciences and Technologies, Department of Computer Systems. E-mail: peteris.rivza @1lu.lv

Kopsavilkums. Ainavas patika cilvēka uztverē iepriekš analizēta dažādos pasaules pētījumos, kur apskatītas gan ainavas estētiskās, gan ekoloǵiskās kvalitātes. Abu kvalitāšu mijiedarbība un nozīmīgums atklājas pilsētas apstādījumu teritorijās, kur mūsdienās īpaši svarīgi ir uzlabot vides ekoloǵisko kvalitāti, neizslēdzot augstvērtīgu ainavas estētisko kvalitāti. Šajā pētījumā analizēti septini ainavas izvēles variant ar atškirīịiem apstādījumu veidiem četrās Latvijas pilsētās. Pētijuma mērḳis bija noskaidrot, Latvijas pilsētu iedzīvotāju un apmeklētāju viedokli un izpratni par pievilcīgu ainavu pilsētvidē. Apstādījumu veidi tika novērtēti balstoties uz ainavas estētiskajām un ekoloğiskajām kvalitātēm - pievilcīgumu, dabiskumu, sakoptību, nepieciešamību pēc regulāras kopšanas, savvaļu, drošību. Rezultāti norādīja, ka pastāv korelācija starp ainavas patiku un respondentu dzimumu, izglīîibas līmeni un dzīvesvietu. Pētījums neatklāja ainavas patikas atšḳirīības četru pêtījumā izvēlēto pilsētu reǵionālo īpatnību kontekstā. Pētỉjuma rezultāti var tikt izmantoti jaunu apstādījumu teritoriju plānošanā un esošu apstādījumu teritoriju atjaunošanā. 